\title{
PENINGKATAN KETERAMPILAN TEKNIK PENGERINGAN KAYU BAGI KELOMPOK PENGRAJIN KAYU DI DESA RUMOONG ATAS
}

\author{
Rolly R. Oroh \\ Jurusan Pendidikan Teknik Bangunan, Fakultas Teknik, \\ Universitas Negeri Manado
}

\begin{abstract}
Abstrak
Kemampuan kerja kayu yang dimiliki oleh kelompok pengrajin kayu di desa mitra masih kurang dan belum bisa menjamin mutu produksi rumah kayu. Permasalahan inti mitra adalah kurangnya informasi, pengetahuan, keterampilan, dan wadah pelatihan tentang bagaimana teknik pengeringan kayu pada penyiapan bahan baku kayu pada industri rumah kayu. Target luaran yang dapat dicapai dalam kegiatan ini, adalah: (a) Terbentuknya masyarakat mitra yang memiliki pengetahuan dan keterampilan yang baik tentang teknologi pengeringan kayu pada industri rumah kayu, sehingga produktifitas dan pola kerja mitra menjadi meningkat; dan (b) Terciptanya profil manajemen usaha yang produktif dan informatif dalam usaha industri rumah kayu. Metode pelaksanaan kegiatan pengabdian ini, berdasarkan kesepakatan dengan masyarakat mitra, adalah: (1) sosilaisasi, (2) pendidikan, dan (3) pendampingan. Hasil yang dicapai dalam pelaksanaan pengabdian ini adalah masyarakat mitra telah memiliki peningkatan pengetahuan dan ketrampilan tentang teknologi pengeringan kayu dalam membangun rumah kayu.
\end{abstract}

Kata Kunci: Teknologi pengeringan kayu, pengrajin kayu, produksi rumah kayu.

\section{PENDAHULUAN}

Pekerja kayu atau pengrajin kayu di desa Rumong Atas, setiap tahun mengalami peningkatan jumlah yang signifikan. Peningkatan ini dikarenakan jumlah pengangguran pada usia produktif adalah pemuda putus sekolah. Ketrampilan kerja kayu yang mereka miliki masih bersifat otodidak (belajar sendiri) dan bersifat turun temurun, hal ini kurang bisa menjamin mutu produksi rumah kayu jika para tukang kayu (pemuda putus sekolah) tidak mengakses informasi tentang perkembangan teknologi.

Industri rumah panggung kayu di desa Rumong Atas relatif cukup memberikan dampak pada peningkatan ekonomi keluarga dan masyarakat, karena jika di lihat dari produksinya, sekitar 5 rumah kayu dapat dihasilkan pada setiap semesternya tergantung ketersedian bahan baku kayu. Dan dari segi pemasarannya, relatif cukup lancar, karena setelah dibuat tidak memerlukan waktu tunggu yang lama (karena biasanya dipajang dipinggir jalan). Sedangkan dari segi tenaga kerja, jika dalam kegiatan memproduksi 1 rumah panggung kayu memerlukan tenaga kerja utama sekitar 20 orang, maka ada ratusan tenaga kerja tukang kayu yang bekerja pada industri rumah kayu yang ada, dan masih terus bertambah jumlahnya. Jumlah tersebut juga belum termasuk dengan tenaga kerja kayu yang bekerja di luar desa, karena tenaga kerja tukang kayu dari desa Rumong Atas, sangat dikenal dengan keterampilan mereka dalam bekerja, sehingga tidak mengheran- 
kan jika banyak desa-desa terdekat menggunakan jasa tenaga kerja tukang kayu dari desa Rumong Atas.

Kelompok usaha kerja sebagai penyedia jasa layanan tenaga kerja tukang bangunan kayu atau pengrajin kayu di desa Rumoong Atas, pada beberapa tahun terakhir dapat dikatakan relatif kurang kompetitif sehingga kalah bersaing dengan tenaga kerja dari luar desa Rumoong Atas, karena dianggap kurang dari segi pengetahuan dan keterampilan dalam membuat rumah kayu dengan usia pakai yang relatif lama. Sehingga hal ini membuat para tukang kayu di desa Rumoong Atas, merasa sangat membutuhkan sentuhan teknologi dalam penerapan teknologi pengeringan kayu, secara khusus teknologi pengeringan kayu yang dapat meningkatkan tingkat keawetan kayu yang berdampak pada usia pakai kayu pada rumah kayu menjadi relatif lebih lama. Hal ini menjadi penting karena ketersediaan bahan baku kayu masyarakat mitra relatif banyak karena merupakan hasil usaha tanaman kayu masyarakat mitra.

Sentuhan teknologi dalam penerapan teknologi pengeringan kayu bagi profesi tukang bangunan kayu atau pengrajin kayu dari masyarakat mitra desa Rumoong Atas, akan berdampak secara ekonomi bagi peningkatan pendapatan penghasilan bagi setiap usaha mereka. Hal ini dapat terjadi oleh karena para pengrajin kayu bukan hanya bekerja diseputar desa Rumoong Atas, tetapi sampai ke desa-desa tetangga, bahkan sampai ke daerah-daerah kabupaten/kota yang lain diseputar sulawesi utara dan juga sampai ke propinsi lain seperti di Papua. Hal ini menjadi suatu peluang yang baik, karena akan berdampak positif bukan hanya pada masyarakat desa Rumoong Atas, tetapi sampai ke luar daerah. Karena dengan pengetahuan dan keterampilan yang didapat oleh para tukang bangunan, tentang bagaimana menerapkan teknologi pengeringan kayu pada industri rumah kayu, mereka akan dapat mentransfernya pada setiap lokasi pekerjaan mereka. Dampak peningkatan pengetahuan dan keterampilan tentang teknologi pengeringan kayu tersebut, dapat meningkatkan kemampuan dan produktifitas kerja serta akan berdampak positif pada pola manajemen kelompok usaha kerja mereka menjadi lebih kompetitif.

Permasalahan mitra menjadi dasar pertimbangan pelaksanaan kegiatan ini, yang selanjutnya didiskusikan bersama sebagai upaya mendapatkan alternatif solusi mengatasi permasalah utama mitra. Adapun beberapa masalah utama mitra adalah: 1) kurangnya informasi, pengetahuan, dan keterampilan tentang bagaimana cara menerapkan teknologi pengeringan kayu pada proses pembuatan rumah kayu; 2) minimnya wadah pelatihan bagi masyarakat mitra untuk semaksimal mungkin mendapatkan kesempatan dalam meningkatkan pengetahuan dan keterampilan mereka, serta memungkinkan mitra untuk memperbaiki dan meningkatkan pola manajemen kelompok 
usaha kerja mereka menjadi lebih produktif dan kompetitif serta informatif. Sehingga dengan permasalahan mitra tersebut, dapat diambil suatu solusi untuk mengatasi permasalahan utama mitra tersebut yaitu, wadah pelatihan tentang teknologi pengeringan kayu pada industri rumah kayu. Alternatif solusi tersebut dapat meningkatkan produktifitas, pola kerja mitra, dan dapat meningkatkan pola manajemen usaha menjadi lebih kompetitif dan informatif.

\section{KAJIAN TEORI}

Proses pengeringan kayu sangat dipengaruhi oleh: 1) Faktor kayu, meliputi jenis kayu dan struktur pori-pori kayu, ketebalan kayu, kadar air kayu awal (initial moisture content), dan kadar air akhir (final moisture content); 2) Faktor penyusunan kayu (stacking) sehubungan dengan ukuran tebal ganjal dan cara penyusunannya dalam oven dan palet. Faktor ini juga dipengaruhi oleh kecepatan sirkulasi udara dalam ruang; 3) Faktor ruang oven meliputi sirkulasi udara dalam ruang, panas energi yang dipasok, dan pengaturan kelembaban relatif dalam ruang untuk mengabsorbsi uap air dari dalam kayu (Budianto, 1996). Faktor-faktor tersebut mempengaruhi kayu dalam menyesuaikan kondisi bagian dalam kayu dengan udara yang ada di sekitarnya, sesuai dengan sifat alami kayu yang higroskopis. Bila kondisi di sekitar kayu terlalu jauh berbeda dengan kondisi dalam kayu, akan timbul ketegangan dalam kayu (drying stesses).
Tegangan dalam kayu timbul karena pelepasan kandungan air yang tidak merata dalam kayu. Bila tegangan ini tidak dapat diatasi dengan cara kembang-susut sel kayu, struktur sel kayu akan terkoyak (Budianto, 1996; Lensufie, 2008).

Sistem pengeringan alami merupakan sistem pengeringan kayu yang paling tua di Indonesia, karena di Indonesia energi matahari sangat murah dan mudah didapat. Batang pohon yang dipotong mempunyai kandungan air sampai 200\% sehingga harus dikeringkan sampai berbulan-bulan, bahkan sampai bertahun-tahun ( 3 bulan sampai 3 tahun) untuk mencapai kadar air yang baik untuk pertukangan. Apalagi, sistem pengeringan alami ini sangat bergantung pada musim dan sinar matahari (Listyanto, 2016; Budianto, 1996). Beberapa pokok-pokok yang perlu diperhatikan pada sistem pengeringan alami: 1) Penggunaan lahan untuk pengeringan relatif luas. Harga dan biaya investasi tanah kini kian melambung, sehingga harus diperhitungkan juga besarnya nilai investasi, bunga investasi dan lama proses pengeringan; 2) Waktu pengeringan relatif lama sehingga stok bahan yang dikeringkan juga harus cukup besar. Bandingkan pula investasi modal kerja (bahan), apakah seimbang dengan biaya operasinya (bunga atas investasi bahan dan tanah akan menyebabkan nilai bahan makin tinggi dan tidak kompetatif); 3) Kayu yang dijemur dapat pecah atau melengkung karena panas matahari yang tidak merata; 4) Waktu pe- 
ngeringan efektif hanya dapat dilakukan selama musim kemarau dan sangat bergantung pada cuaca; dan 5) Kadar air kayu umumnya hanya mencapai sekitar 15\%, yang relatif masih tinggi.

Pengeringan kayu buatan dibedakan menjadi 5 tahapan proses, yaitu: 1) tahap pemanasan awal (preheating); 2) tahap pengeringan kayu sampai titik jenuh serat (drying down to fibre saturation point); 3) tahap pengeringan dari titik jenuh serat sampai kadar air akhir (drying down from FSP to Final Moisture Content); 4) pengkondisian pada kadar air akhir (conditioning at $F M C$ ); dan 5) pendinginan dan pembongkaran kayu (cooling down and discharge of timber stack) (Budianto, 1996; Awaludin \& Irawati, 2017; Wardi \& Soewarsono, 2000).

Tujuan utama proses pengeringan kayu dalam industri kayu, adalah untuk meningkatkan mutu kayu dan mempermudah pengerjaan berikutnya. Kecenderungan rusak selalu lebih besar daripada persentase hasil baiknya bila kita tidak dapat mengendalikan mesin pengering kayu. Kesalahan atau cacat kayu harus dapat dicegah dan diatasi sebelum kita melangkah lebih lanjut. Pedoman yang harus dipegang adalah bahwa nilai kayu yang diproses adalah besar, sekali salah berakibat fatal. Oleh karena itu, proses pengeringan kayu dan karakteristik kayu yang dikeringkan harus dapat dikontrol dan dikuasai. Proses pengeringan tidak dapat dipaksa atau dipercepat hanya dengan menaikkan temperatur ruang begitu saja. Bila hal ini dilakukan bukan hasil yang bermutu baik dan proses pengeringan cepat yang didapat, melainkan kayu rusak dan cacat sehingga tidak dapat dimanfaatkan. Cacat kayu yang terjadi tidak selalu akibat kesalahan pengeringan, dapat juga berasal dari: a) saat tumbuh (alami); b) penebangan dan penanganan log yang salah; dan c) proses penggergajian (saw mill) (Budianto, 1996; Mulyono; Sumarni; 2010).

\section{METODE PELAKSANAAN}

Metode pelaksanaan kegiatan pengabdian ini, dipilih setelah dilakukan inventarisasi dan identifikasi serta penetapan permasalahan mitra. Selanjutnya penetapan permasalahan utama mitra tersebut menjadi dasar pertimbangan dan pembahasan tim pelaksana pengabdian UNIMA bersama mitra untuk menetapkan metode pelaksanaan yang tepat dan sesuai kebutuhan mitra. Adapaun metode pelaksanaan kegiatan pengabdian ini, berdasarkan kesepakatan dengan masyarakat mitra, adalah: 1) sosialisasi; 2) pendidikan; dan 3) pendampingan.

Tahapan sosialisasi diawali dengan melakukan penyuluhan tentang pentingnya menerapkan teknik pengeringan kayu pada bahan baku kayu untuk pembuatan rumah kayu. Dalam kegiatan penyuluhan ini, diberikan juga contoh-contoh kasus tentang keuntungan dan kelebihan dalam penerapan teknik pengeringan kayu pada produk rumah kayu, dengan harapan dapat memberikan suatu kesadaran masyarakat akan pen- 
tingnya menerapkan teknologi pengeringan kayu pada setiap bahan baku kayu untuk dijadikan bahan baku pembuatan rumah kayu.

Tahapan pendidikan dilakukan setelah masyarakat mitra memiliki kesadaran, dilanjutkan dengan tahapan pemberian materi teknologi pengeringan kayu yang aplikatif tentang cara-cara penerapan teknik pengeringan kayu pada penyiapan bahan baku kayu. Adapun materi yang akan diberikan diambil dari berbagai sumber referensi. Cara pemberian materi ini, sesuai kesepakatan dengan mitra pengabdian, akan dilakukan dengan cara pemberian langsung ke tempat-tempat pelaksanaan pembangunan rumah kayu di desa Rumoong Atas yang sementara berlangsung, dengan maksud untuk lebih memaksimalkan proses pemberian materi karena langsung ditunjukkan cara-caranya dilokasi pekerjaan.

Tahapan pendampingan dilakukan berbarengan atau bersama-sama dengan proses pemberian materi pelatihan, dengan maksud untuk memberikan konsultasi dan pendampingan kepada pemilik usaha dan para pengrajin kayu, untuk tidak mengabaikan cara-cara teknik pengeringan kayu, sekaligus menerapkannya pada proses produksi rumah kayu.

\section{HASIL DAN PEMBAHASAN}

\section{Hasil yang Dicapai}

Pelaksanaan kegiatan pengabdian ini yang dilakukan di desa Rumoong Atas, kepada mitra yakni kelompok usaha pengrajin kayu, dapat dikatakan relatif berhasil. Keberhasilan ini dapat diukur, diamati dan atau dilihat bahwa masyarakat mitra mera-sa ada pengetahuan dan keterampilan yang lebih modern yang didapat melalui kegiatan ini. Dalam proses pemberian materi, menunjukkan bahwa masyarakat mitra sangat berantusias untuk mengikuti pelatihan ini, hal tersebut diindikasikan dengan keaktifan mitra pada pelaksanaan kegiatan, baik pada materi bersifat teori (pengetahuan) maupun materi pelatihan bersifat terapan (keterampilan).

Ketrampilan kayu yang dimiliki oleh mitra pengabdian yakni kelompok pengrajin kayu di desa Rumoong Atas, ternyata sangat beragam, dari yang masih memiliki keterampilan cukup sampai yang sudah dianggap memiliki keterampilan yang sangat baik, tetapi dapat disimpulkan bahwa para peserta masih merasa kurang dengan pengetahuan dasar-dasar teknologi pengeringan kayu. Pertimbangan tersebut menjadi dasar sehingga dalam pelatihan ini perlu diberikan beberapa materi yang bersifat teori yang membahas tentang teknologi pengeringan kayu dalam membuat rumah panggung berbahan kayu yang awet atau tahan lama, dan didukung oleh beberapa literatur yang relevan, dan selalu disesuaikan dengan kebutuhan mitra.

Pemberian materi pilihan yang sesuai dengan kebutuhan peserta, maka dapat dikatakan bahwa, pelaksanaan pelatihan ini 
dapat menambah tingkat kecakapan hidup dari peserta tentang teknologi pengeringan kayu, hal ini dapat dilihat bahwa peserta merasa ada pengetahuan baru yang didapat tentang teknologi pengeringan kayu. Dikatakan pengetahuan baru oleh peserta, karena diawal pelatihan, dasar ketrampilan yang di miliki oleh peserta hanya bersifat otodidak atau bersifat turun temurun dari para orang tua mereka, atau dari teman kerabat mereka yang lebih tua dan berpengalaman. Melalui diskusi dengan mitra, maka disepakati beberapa materi pilihan tentang teknologi pengeringan kayu. Hasil diskusi tersebut menjadi dasar pertimbangan sehingga dalam kegiatan ini perlu diberikan beberapa materi yang bersifat teori dan aplikatif tentang: 1) Hakekat dan pentingnya teknologi pengeringan kayu dalam mem-buat rumah panggung kayu; dan 2) Metode dan langkah kerja dalam menerapkan teknologi pengeringan kayu.

Pelaksanaan pemberian materi pelatihan, diawali dengan tahapan sosialisasi tentang pentingnya teknologi pengeringan kayu bagi bahan kayu yang akan dijadikan bahan membuat rumah kayu. Selanjutnya dilakukan tahapan pemberian materi pendidikan, dengan cara diberikan langsung ditempat-tempat proses pembangunan rumah kayu, dengan maksud untuk lebih memaksimalkan proses pemberian materi, karena langsung ditunjukkan dalam membangun rumah kayu. Pada tahap pemberian materi, diberikan juga materi tentang pola manaje- men usaha jasa layanan pertukangan agar menjadi lebih kompetitif dan informatif dan lebih dikenal luas oleh masyarakat. Setelah pemberian materi pendidikan selesai, dilanjutkan dengan tahapan pendampingan, yang dilakukan dengan cara turun langsung dilokasi pekerjaan dan atau melakukan komunikasi antara mitra pengabdian dengan tim pelaksana pengabdian Unima. Kegiatan pendampingan dilakukan untuk lebih mengoptimalkan materi tentang teknologi pengeringan kayu yang diberikan, agar mitra lebih memiliki tingkat pengetahuan yang baik dan lebih modern tentang teknologi pengeringan kayu.

Metode dan atau solusi pendekatan yang dipilih dalam pelaksanaan kegiatan ini dapat dikatakan sukses dengan memberikan hasil yang baik bagi mitra. Hasil yang dicapai dalam pelaksanaan pengabdian ini adalah masyarakat mitra telah memiliki peningkatan pengetahuan dan ketrampilan tentang teknologi pengeringan kayu dalam membangun rumah kayu, seperti tergambar pada Tabel 1. Sehingga metode yang dilakukan untuk kegiatan ini dapat dikatakan sangat berhasil, yakni diawali dengan diskusi awal dengan mitra untuk melihat dan menganalisis kebutuhan mereka, dan diakhiri dengan kesepakatan metode dan materi yang sesuai dengan kebutuhan riil mitra.

Pelaksanaan kegiatan ini, tidak terlepas dari berbagai hambatan yang dihadapi pada setiap tahapan kegiatan pengabdian ini. Hambatan-hambatan tersebut, seperti ke- 
lompok mitra dengan beberapa anggotanya, kadangkala mengalami kendala waktu dan kesempatan untuk secara penuh mengikuti kegiatan ini. Hambatan-hambatan tersebut seperti para anggota kelompok kerja telah lebih dahulu menerima tawaran kerja dari lokasi atau temopat kerja yang lain, sehingga membuat tim pelaksana berusaha untuk selalu menyesuaikan waktu dengan mitra karena diwaktu bersamaan, mitra harus menyelesaikan pekerjaan mereka, sementara tim pelaksana pengabdian telah diatur waktu pelaksanaannya. Dengan demikian, di waktu mendatang pada kegiatan seperti ini perlu dilakukan penyesuaian waktu secara bersama antara mitra dan tim pengabdi.

Tabel 1. Kondisi dan keadaan mitra setelah pemberian materi pendidikan

\begin{tabular}{|c|c|c|c|}
\hline No & Uraian materi & Kondisi awal & Kondisi akhir \\
\hline A. & Sosialisasi: & & \\
\hline 1. & $\begin{array}{l}\text { Hakekat dan pentingnya penerapan } \\
\text { teknologi pengeringan kayu bagi usaha } \\
\text { rumah kayu }\end{array}$ & Cukup & Lebih baik \\
\hline B. & Pendidikan: & & \\
\hline 2. & $\begin{array}{l}\text { Metode dan langkah kerja dalam } \\
\text { menerapkan teknologi pengeringan kayu }\end{array}$ & Cukup & Lebih baik \\
\hline C. & Pendampingan: & & \\
\hline 3. & $\begin{array}{lll}\text { Optimalisasi penerapan } & \text { teknologi } \\
\text { pengeringan kayu di lokasi kerja } & \end{array}$ & Tradisional & $\begin{array}{l}\text { Baik \& lebih } \\
\text { modern }\end{array}$ \\
\hline
\end{tabular}

Tabel 2. Indikator capaian kegiatan pengabdian.

\begin{tabular}{|c|c|c|c|}
\hline \multirow[b]{2}{*}{ No } & \multirow[b]{2}{*}{ Target luaran } & \multicolumn{2}{|c|}{ Indikator capaian } \\
\hline & & $\begin{array}{l}\text { Sebelum } \\
\text { kegiatan } \\
\text { (existing) }\end{array}$ & Sesudah kegiatan \\
\hline 1 & $\begin{array}{l}\text { terbentuknya masyarakat mitra yang } \\
\text { memiliki pengetahuan dan keterampilan } \\
\text { yang baik tentang teknologi pengeringan } \\
\text { kayu, sehingga produktifitas dan pola kerja } \\
\text { mitra menjadi meningkat }\end{array}$ & Kurang & $\begin{array}{lr}\text { Mitra mengakui } r & \text { ada } \\
\text { pengetahuan } & \text { dan } \\
\text { keterampilan baru yang } \\
\text { didapat. }\end{array}$ \\
\hline 2 & $\begin{array}{l}\text { terbentuknya pola manajemen usaha } \\
\text { pengrajin kayu menjadi lebih kompetitif dan } \\
\text { informatif (lebih dikenal luas oleh } \\
\text { masyarakat) }\end{array}$ & $\begin{array}{l}\text { Bersifat } \\
\text { tradisional }\end{array}$ & $\begin{array}{lr}\text { Tersedianya } & \text { jejaring } \\
\text { komunikasi } & \text { dengan } \\
\text { kelompok yang lain } & \end{array}$ \\
\hline
\end{tabular}

\section{Luaran yang Dicapai}

Pelaksanaan kegiatan ini, dengan metode dan materi yang dipilih bersama masyarakat mitra, memberikan capaian beberapa luaran utama kegiatan (Tabel 2). Luaran yang dicapai pada kegiatan ini dapat dijadikan sebagai suatu keberhasilan kegiatan ini.
Adapun target luaran utama melalui pelaksanaan kegiatan ini adalah: a) terbentuknya masyarakat mitra yang memiliki pengetahuan dan keterampilan yang baik tentang teknologi pengeringan kayu, sehingga produktifitas dan pola kerja mitra menjadi meningkat; dan b) terbentuknya pola pola manaje- 
men usaha jasa layanan menjadi lebih kompetitif dan informatif (lebih dikenal luas oleh masyarakat).

\section{KESIMPULAN DAN SARAN}

Pelaksanaan kegiatan pengabdian ini yang dilakukan di desa Rumoong Atas, kepada mitra yakni kelompok usaha pengrajin kayu, dapat dikatakan relatif berhasil. Keberhasilan ini dapat diukur, diamati dan atau dilihat bahwa masyarakat mitra merasa ada pengetahuan dan keterampilan yang lebih modern yang didapat melalui kegiatan ini. Materi yang diberikan kepada mitra merupakan materi yang disepakati melalui diskusi dengan mitra. Sehingga metode dan atau solusi pendekatan yang dilakukan untuk kegiatan ini dapat dikatakan relatif berhasil, yakni diawali dengan diskusi awal dengan mitra untuk melihat dan menganalisis kebutuhan mereka, dan diakhiri dengan kesepakatan metode dan materi yang sesuai dengan kebutuhan riil mitra. Hasil yang dicapai dalam pelaksanaan pengabdian ini adalah masyarakat mitra telah memiliki peningkatan pengetahuan dan ketrampilan tentang teknologi pengeringan kayu dalam membangun rumah kayu.

\section{UCAPAN TERIMA KASIH}

Ucapan terima kasih yang tulus dari kami tim pelaksana kepada Rektor, Ketua LPPM dan Dekan Fakultas Teknik UNIMA, serta semua pihak yang telah membantu dan memberi kesempatan untuk pelaksanaan kegiatan ini.

\section{KEPUSTAKAAN}

Awaludin, A., dan Irawati, I.S., 2017, Konstruksi Kayu, Biro Penerbita: Teknik Sipil Universitas Gadjah Mada, Yogyakarta.

Budianto, A.D., 1996, Sistem Pengeringan Kayu, Pendidikan Industri Kayu Atas Semarang, Penerbit Kanisius, Yogyakarta.

Lensufiie, T., 2008, Mengenal Teknik Pengeringan Kayu, Esensi Erlangga Group - PT. Gelora Aksara Pratama, Jakarta.

Listyanto, T., 2016, Teknologi Pengeringan Kayu dan Aplikasinya di Indonesia, Gadjah Mada University Press, Yogyakarta.

Moelyono, S.B., Pengantar Perkayuan, PIKA Semarang, Semarang.

Sumarni, S., 2010, Struktur Kayu, Yuma Pustaka, Bandung.

Wardi \& Soewarsono, 2000, Penyelidikan Pendahuluan tentang Sifat-sifat Fisik dan Mekanik Kayu-kayu di Indonesia, Bogor. 